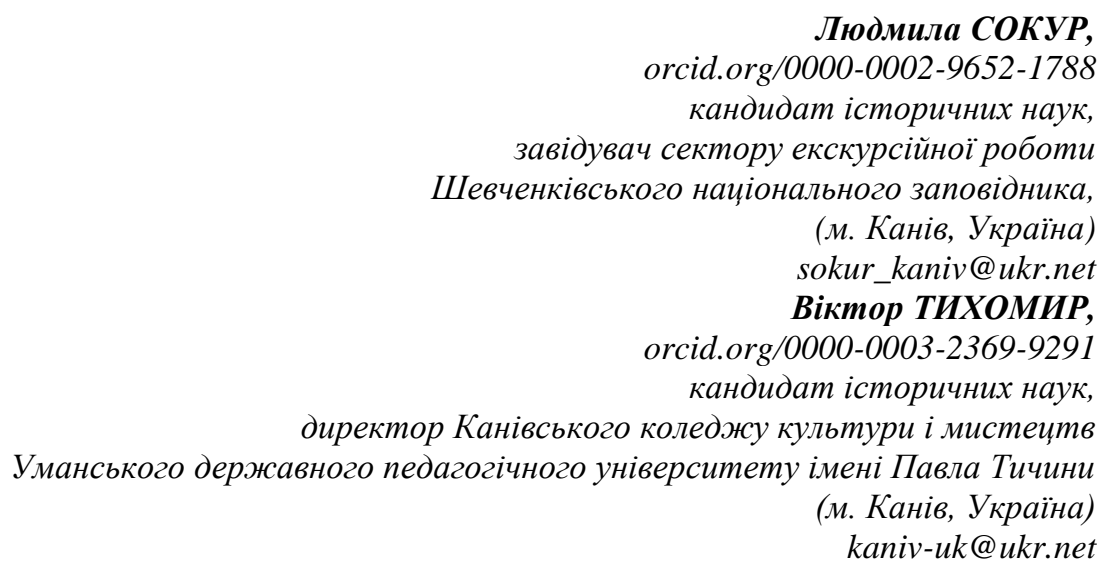

\title{
ГАЙДАМАЦЬКИЙ РУХ НА ЧЕРКАЩИНІ / РЕГІОНАЛЬНІ ВИМІРИ УКРАЇНСЬКОЇ ІСТОРІЇ У ТВОРЧОСТІ ТАРАСА ШЕВЧЕНКА
}

\begin{abstract}
У статті досліджується перебіг подій гайдамацького руху на Черкащчині як вагомого явищза регіональної історії; проводиться аналіз причин, щзо призвели до його появи у XVII столітті та поклали передумови для повстання Колї̈вини, дається оијнка діяльності польської иляхти, украӥнських повсталих загонів та ватажків гайдамацького повстання 1768 року з позиції суспільно-політичних поглядів першої половини ХІХ століття, щуо простежуються у творчості та історичних переконаннях Тараса Шевченка; визначається місце та роль подій регіональної історії у контексті загальної історії України.
\end{abstract}

Ключові слова: Черкащина, гайдамацький рух, Колївщчина, творчість Тараса Шевченка, історичні погляди, український народ.

\author{
Lyudmyla SOKUR, \\ PhD, Head of the excursion sector of the \\ Shevchenko National Reserve (Kaniv, Ukraine) \\ sokur_kaniv@ukr.net \\ Victor TYKHOMYR, \\ $P h D$, Director of the Kaniv College \\ of Culture and Arts \\ Uman State Pedagogical University \} \\ named Pavlo Tychyna (Kaniv, Ukraine) \\ kaniv-uk@ukr.net
}

\section{HAYDAMAK'S MOVEMENT OF CHERCASSY REGION DIMENSIONS OF UKRAINIAN HISTORY THROUGH THE TARAS SHEVCHENKO'S CREATIVITY}

In this article investigating the course of events of the Haydamak's movement on Cherkassy Region as important phenomenon in regional history. Analizing reasons which provoke the movement in XVIII century and background to the Koliyivshchyna. Estimated the activity of the polish nobility, ukrainian insurgent groups, main leaders of Haydamak's rebellion in 1768 from position of socio-political views of the first part of XIX century, what can be well seen through the prism of Taras Shevchenko's creativity and historical views. Determined the place and a role of regional history events in a context of history of Ukraine. The main thesis of the article is describing an events of the Haydamak's movement on Cherkassy Region as important aspect of regional history in a context of the Taras Shevchenko's creativity and political views, its role in the history of Ukraine.

Taras Shevchenko one of the first poets who increased the problem of Haydamachyna and its interpritation in the first part of XIX century. Taras Shevchenko was showing historical events through the context of the citizens' views, direct participants of the Haydamak's rebellion. It gave the possibility to understand not just historical conditions and 
reasons in which national liberation perfomances were happened, but also the motivation of their movements. Interpretation of the Haydamak's movement was showed by Taras Shevchenko in his poem «Haydamaky». For a long time this poem was like a reliable information, which showed the rebilion of 1768 on the Right-Bank Ukraine.

Poetic rethinking of the haydamak's movement like an important historical phenomenon gave for Taras Shevchenko the possibility to analyze the specific historical conditions in which the haydamak's events were developing. It helped him to pay attention to the humiliating policy of Rzecz Pospolita regarding Ukrainian people. The intervention of Russian Imperial leaders into Ukrainian-Polish conflict helped to come to the conclusion that experience of national liberation struggle of the second part of XVIII century could become for future generations as a useful source for analyzing achievements and failures to escape such situations in future.

The most important role in Koliivshchyna played the Cherkassy Region. On this territory was living and working Mykhaylo Maksymovich, one of the first researcher of this phenomenon in the history of Ukraine. Taras Shevchenko the author of poetic interpretation of the Koliivshchyna's events of 1768. It was the motherland of the most leaders of Haydamak's movement. Especially, Taras Shevchenko was paying attention that social and political movement which was formed in Cherkassy Region was transformed into national liberation phenomenon which was spread on other regions of Ukraine ( Kyiv Region, Polissya, Volyn etc). This movement made influence not just on the history of Ukraine, but for all other countries also.

The climax of the haydamak's movement became the rebilion on 1768, which was called as Koliivshchyna. This final step of haydamak's movement became the answer for the behaviour of Polish people on regional level. In this way was showed the huge possibilities of the Ukrainian people of self-organization. Taras Shevchenko could do not just feel, but in the same time tell the events of the past. He became an orientation for understanding phenomenon of Haydamachyna like on the regional level and at the same time for the whole history of Ukraine.

Key words. Cherkasy region, Haydamak's movement, Koliyivshchyna, Taras Shevchenko's creativity, historical views, Ukrainian nation.

Постановка проблеми. Історія держави складається з безлічі самобутніх регіональних історій, які творять пересічні громадяни, патріоти, чиї імена назавжди вписані у книгу пам'яті українського народу. До таких постатей належать видатний поет і художник Тарас Шевченко, у творчості якого оживають сторінки української історії, зокрема, гайдамаччини.

Гайдамацький рух на українських землях - героїчне і водночас трагічне явище в історії українського народу, яке викликає активну наукову дискусію, а відтак, потребує додаткового осмислення.

Аналіз досліджень. Не зважаючи на те, що від часів активізації гайдамацького руху і Коліївщини минуло вже понад 250 років, проте інтерес до цього суспільно-політичного явища національного життя українського народу Правобережної України і досі не згасає. Свідченням цього є публікації Олексія Барановського (Барановський, 2011: 17-20), Петра Гончарука (Гончарук, 2008: 77-82), Юрія Мицика (Мицик, 2002), Володимира Мільчева (Мільчев, 2005: 48-56), Данила Мордовцева (Мордовцев, 2003), Володимира Омельчука (Омельчук, 2002), Ольги Посунько (Посунько, 2010: 248-259), Тараса Чухліба (Чухліб, 2008: 116-125) та інших.

Метою статті $\epsilon$ висвітлення подій гайдамацького руху на Черкащині як 
вагомого аспекту регіональної історії у контексті поетичної творчості та історичних поглядів Тараса Шевченка та їх роль у загальній історії України.

Виклад основного матеріалу. Вперше до теми гайдамаччини наукова спільнота звернулась ще в I половині XIX століття, коли події Коліївщини ще міцно жили в пам’яті свідків тих подій та їх нащадків. Серед українських вчених першим звернув увагу на проблему гайдамацького руху Михайло Максимович у статті «Сказание о Колиивщине», опублікованій у газеті «Киевлянин» ще у 1839 році. Автор статті висловлював прихильне ставлення до самого явища гайдамацького руху, як національно-визвольної боротьби українського народу, та виправдовував Коліївщину, тому не дивно, що незабаром цензурою дана стаття була заборонена.

1842 року у Москві світ побачила праця Миколи Маркевича «История Малороссии», у другому томі якої також висловлювалось позитивне ставлення до Коліївщини.

Проте ще роком раніше у Санкт-Петербурзі в альманасі «Ластівка» світ побачив один із розділів поеми «Гайдамаки» Тараса Шевченка, пізніше названий «Галайда». Цього ж 1841 року поему «Гайдамаки» було опубліковано окремим виданням.

У «Передмові» до «Гайдамаків» Тарас Шевченко зазначає, що «Про те, що діялось на Україні 1768 року, розказую так, як чув од старих людей; надрукованого і критикованого нічого не читав, бо, здається, і нема нічого...» (Шевченківська енциклопедія, 2012: 27, 29).

Поруч 3 тим, у «Приписах» (коментарях) до першого видання «Гайдамаків» Тарас Шевченко посилається на окремі літературні джерела, що лягли в основу поеми, це зокрема, «Энциклопедическій лексиконъ», «Исторія государства Польскаго» Георга Вандтке, «Історія Русів» Георгія Кониського, «Історія Малої Росії» Дмитра Бантиш-Каменського та інші.

Отже, вище зазначені обставини дозволяють нам стверджувати, що Тарас Шевченко, поруч з Михайлом Максимовичем, є одним з перших дослідників та інтерпретаторів подій гайдамацького руху та Коліївщини 1768 року. 3 огляду 
на це, хочемо більш детально зупинитися на окремих аспектах поеми, що дозволить нам побачити події того часу з позиції учасників та очевидців тих подій, та розглянути їх як у контексті регіональної історії, так і історії України у цілому.

При викладенні подій гайдамацького руху і Коліївщини, Тарас Шевченко опирався передусім на розповіді діда Івана, який ще підпарубком брав участь у повстанні й розповідав про це родині та на народні перекази, зазначаючи у передмові до «Гайдамаків», що може не все написав так як воно було, проте «смерть вільшанського титаря правдива, бо ще є люди, которі його знали». Поруч $з$ тим, автор поеми не заперечує присутності у творі художнього домислу і в передмові пише: «Галайда вполовину видуманий» та припускає, що можуть бути допущені й інші певні неточності, зокрема «Гонта і Залізняк, отамани того кровавого діла, може, виведені в мене не так, як вони були,- за це не ручаюсь. Дід мій, нехай здоров буде, коли зачина розказувать що-небудь таке, що не сам бачив, а чув, то спершу скаже: «Коли старі люди брешуть, то й я 3 ними» (Шевченко, 2003b: 201).

У XIX столітті поетичне слово Тараса Шевченка мало велику силу i переконливість серед його сучасників. У своїх творах поет звертався до народу, мовою народу, піднімаючи проблеми його рідного українського народу. Тому й не дивно, що довгий час до появи історичних досліджень про Коліївщину читачі «Гайдамаків» були впевнені, що саме так, як показано в поемі, протікало народне повстання 1768 року на Правобережній Україні.

Пам’ять про події, пов’язані з гайдамацькими повстаннями була ще зовсім свіжою, ще живими лишались свідки тих героїчних і, водночас трагічних подій, які берегли спомини про колишню звитягу козаків.

Черкащина не лише була охоплена гайдамацьким рухом, а й стала осередком масштабного повстання Коліївщини 1768 року, яке розпочалося його проголошенням на Зелені Свята в Мотронинському манастирі (травень 1768 року). Саме сюди роком раніше прибув організатор і очільник Коліївщини козак Максим Залізняк для підготовки одного з найбільших повстань в історії 
XVIII століття (Мірчук, 1973).

Перекази, легенди, бувальщини про події козаччини та гайдамаччини ще міцно побутували серед народу, переповідались дітям, онукам, обростали героїкою та ідеалізувались. Тому цілком закономірним було те, що представники нового покоління українців надзвичайно захоплювалися минувшиною. Для Тараса Шевченка це було не просто захоплення; як онук свідка тих подій, він ще змалечку чув розповіді рідного діда Івана Андрійовича Шевченка-Грушівського та успадкував героїчні традиції гайдамаків.

Досвід боротьби гайдамацьких загонів та повстання Коліївщини, на думку Тараса Шевченка, могли б стати для прийдешніх поколінь корисним джерелом для аналізу здобутків та прорахунків, щоб уникнути подібних ситуацій у майбутньому. Про що, зокрема, свідчать слова поета в передмові до поеми «Гайдамаки»: «...весело подивиться на сліпого кобзаря, як він собі сидить 3 хлопцем, сліпий, під тином, і весело послухать його, як він заспіває думу про те, що давно діялось, як боролися ляхи з козаками; весело... а все-таки скажеш: «Слава Богу, що минуло», - а надто як згадаєш, що ми одної матері діти, що всі ми слав'яне. Серце болить, а розказувать треба: нехай бачать сини і внуки, що батьки їх помилялись, нехай братаються знову з своїми ворогами. Нехай житом-пшеницею, як золотом покрита, не розмежованою останеться навіки од моря і до моря слав'янськая земля...» (Шевченко, 2003b: 201).

Проте державний лад Речі Посполитої, заснований на засадах шляхетської демократії, призвів до сваволі польської шляхти та магнатів на землях Правобережної України. Про що Тарас Шевченко пише:

Пожар не гасне, люди мруть,

Конають в тюрмах, голі, босі...

Діти нехрещені ростуть,

Козацькі діти... (Шевченко, 2003а: 155)

Аналіз подій гайдамаччини підводять Тараса Шевченка до розуміння ним причин та природи цього явища на українських землях. Він не шукав виправдання жодній із сторін, він лише пояснював причини та передумови, що 
призвели до цього: «...Украйну катували ляхи скажені...», «Горілки, крові упивались...», «...розпинали, кляли, що нічого вже взять...» (Шевченко, 2003а: 157), «... і кров'ю за кров, і муки за муки!..» (Шевченко, 2003а: 166). Наголошував на тому, що саме політика Речі Посполитої спонукала до консолідації національно-визвольних сил українського народу, поєднуючи зусилля представників різних соціальних груп і верств:

У темному гаю,

Зібралися; старий, малий,

Убогий, багатий

Поєднались...(Шевченко, 2003a:148]

...Осталися

Діти та собаки,-

Жінки навіть $з$ рогачами

Пішли в гайдамаки... (Шевченко, 2003a:165)

У праці Петра Мірчука, який досліджує перебіг повстання Коліївщини знаходимо підтвердження тому, що кульмінаційні події в Умані в червні 1768 року могли б набути зовсім іншого розвитку. Дослідник пише: «...ранком 21-го червня (н. ст.) недалеко брами появився Гонта 3 білою хоруговкою, викликаючи Младановича на переговори, той погодився і казав впустити до міста Гонту й гурт його охорони. Але у брамі виникло замішання, бо польські старшини, не дбаючи про збереження вимоги безпеки мирової делегації, кинулися зі зброєю на Гонту, щоб його вбити. Вив'язалась боротьба, в часі якої у відкриту браму вскочило більше повстанців, а за ними ввійшли й головні сили коліїв. Наступила кривава розправа [..], в якій загинуло від п'яти до вісімнадцяти тисяч осіб польської шляхти й жидів» (Мірчук, 1973) (підкреслення наше. - Авт.). Слід зауважити, що ще 3 козацьких часів білий прапор у міжнародних відносинах визнавався як прохання або вимога про припинення військових дій, знак перемир'я або пропозиція переговорів. Проте польська делегація порушила ці норми права, накинувшись на представників мирової делегації. Отже, якщо польська сторона, перебуваючи у вкрай 
скрутному та небезпечному для себе становищі відверто проігнорувала міжнародні правові норми, то можемо лише уявити, якими ж були іiі дії по відношенню до безправного українського селянства. Якби дії польської сторони не спровокували повстанців своїми агресивними діями, то, ймовірно, цей конфлікт, як і багато інших, завершився б укладенням нових домовленостей та поступками, що дозволило б дещо зняти суспільну напругу і перейти на нові щаблі переговорів.

Петро Мірчук зауважує, що багато польських жінок і дітей урятував від загибелі Іван Гонта, доручивши перевести їх до української церкви, або до своєї квартири в домі українського міщанина Багатого, а між ними й дочку та сина губернатора Младановича, які залишили опісля свої спомини про події в Умані (Мірчук, 1973).

Підкреслюючи принциповість та рішучість Івана Гонти у боротьбі зі шляхтою, Тарас Шевченко підсилює емоційний ефект його сприйняття, подаючи сцену вбивства ним власних дітей, народжених від дружини польки. Проте, цей факт не знайшов свого підтвердження, та й вище згадані вчинки Івана Гонти заперечують можливість його існування.

Про те, що повсталі на чолі з Іваном Гонтою не планували чинити ніякої розправи над польською шляхтою свідчать і спогади нащадка відомих польських шляхетських козацьких родів Михайла Чайковського, який переповідаючи розповідь врятованого сина губернатора Младановича, хрещеника Івана Гонти, зазначав: «Удивительная вещь - он не выражал ни ненависти, ни раздражения против Гонты. Всю вину преступления он приписывал Феликсу Потоцкому и польской шляхте. Вот слова, которые я часто слышал от него: «выучили его читать, писать [...] и понемножку всяким наукам, а потом хотели его бить, сажать в «гусак»; сделали его полковником, а полковник он был дельный, потому что он лучше знал военное дело, чем региментари, бригадиры и ротмистры, - а потом хотели его ошельмовать, как хама, мужика; и муравей кусает, если ему досаждают, а что же человек, да еще такой как Гонта? Паны наварили этого пива, а люд Божий должен был его пить 
- и пьет, да никак не выпьет до дна» (Записки Михаила Чайковского, 1891).

Окатоличення, ополячення, нехтування звичаями і традиціями, безправ'я найчисельнішої, прикріпленої до землі та поміщиків, верстви селян, національне гноблення - все це сприяло зародженню невдоволення в українському селянському середовищі, яке на початку XVIII століття вилилось у формування гайдамацьких загонів, тісно пов'язаних 3 Черкащиною, де проходило дитинство Тараса Шевченка. Тому події української минувшини, у тому числі й гайдамаччини, знайшли своє відображення не лише у вище згадуваній поемі «Гайдамаки» (1841), а й у інших, як поетичних, так і прозових творах: «Холодний яр» (1845), «Швачка» (1848), «Прогулка с удовольствием и не без морали» та інших. Через канву художніх образів і сюжетів, автор подає реалістичний масштаб розмаху цих повстань, їх територіальні межі; знайомить читачів з регіонами, які були їх епіцентрами: «Зайнялася Смілянщина...А найперша Медведівка...Горить Корсунь, Горить Канів, Чигирин, Черкаси...Аж у Волинь. По Поліссі...» (Шевченко, 2003a: 160-161).

Аналіз історичного минулого України дає Шевченкові підстави говорити про російське втручання в українсько-польський конфлікт, шляхом забезпечення повсталих такою необхідною для них зброєю. Підтвердження цьому знаходимо у наступних рядках:

Понад дібровою стоять

Вози залізної тарані:

То щедрої гостинець пані.

Уміла що кому давать... (Шевченко, 2003а: 149).

Слід пригадати, що утворення Барської конфедерації 1768 року стало наслідком втручання Російської імперії у внутрішні справи Речі Посполитої та підтримкою польським королем Станіславом Августом Понятовським проросійської політики. Російсько-польське протистояння на землях Правобережної України супроводжувалось масовими розправами над православними, що призвело до піднесення гайдамацького руху і Коліївщини. Про що Тарас Шевченко пише: 
Розбрелись конфедерати

По Польщі, Волині,

По Литві, по Молдаванах

І по Україні...

Руйнували, мордували,

Церквами топили...

А тим часом гайдамаки

Ножі освятили... (Шевченко, 2003a: 135).

Використовуючи різні сюжетні лінії у подачі власної інтерпретації гайдамацького руху, Тарас Шевченко дає зрозуміти, що в його основі була боротьба українського козацтва і селянства за волю, за землі, конфісковані польськими магнатами, за ліквідацію національного приниження, за збереження православ'я тощо.

Особливо Т.Г.Шевченко відзначав роль Черкащини, як осередка гайдамацького руху. Наголошуючи на тому, що, передусім, повстанням було охоплено землі Сміли, Корсуня, Канева, Черкас, Чигирина, які є ядром України, а потім сягнули більш віддалених місць України, зокрема Полісся і Волині, перерісши з суспільно-політичного явища регіонального рівня на масштабний національно-визвольний рух, що вплинув не лише на подальшу історію українського народу, а й інших держав.

Зауважимо, що саме гайдамацький рух та національно-визвольне повстання Коліївщина 1768 року стали приводом до занепаду Речі Посполитої, втручання у її справи Російської імперії і, врешті-решт, поділу Речі Посполитої, у результаті якого до Російської імперії відійшли протягом 1772-1795 років східнобілоруські землі з Полоцьком, Вітебськом та Мстиславлем, частина Латвії (1772); Київщина, Східна Волинь, Поділля, Брацлавщина та білоруські землі (1793); Литва, Курляндія, Західна Білорусь та Західна Волинь (1795). Як бачимо, після третього поділу Польщі і правобережна частина Черкащини відходить до Росії, утворивши крім лівобережного Золотоніського повіту Полтавської губернії ще п'ять повітів Київської губернії - Звенигородський, 
Канівський, Уманський, Черкаський і Чигиринський. В наступному столітті територія краю вже була епіцентром гайдамацького руху, кульмінацією якого стало повстання Коліївщина 1768 року. Уродженцями краю були Максим Залізняк, Іван Гонта, Йосип Шелест та інші ватажки цього повстання.

Висновок. Гайдамацький рух та Коліївщина 1768 року стали ні чим іншим як місцевою регіональною відповіддю на свавільну політику польської шляхти, що отримала на цих землях володіння після входження українських земель до складу Речі Посполитої. Охопивши Черкащину, визвольний рух поширився й на інші регіони, що відзначалися скупченістю поселень польських магнатів, де суспільно-політична ситуація мало чим відрізнялась від ситуації на Черкащині. У ході цих виступів були продемонстровані величезні можливості самоорганізації різних верств суспільства на місцевому регіональному рівні, на чому наголошував Тарас Шевченко в поемі «Гайдамаки». Щодо інтерпретації історичного минулого, Юрій Мушкетик зауважує, що «Шевченкові вдавалось точно вловити і влучно відобразити у своїх творах суть кожної постаті й події, хоч би якою контроверсійною та неоднозначною вона була... I це не зважаючи на те, що за часів Шевченка історія України була малодослідженою і для іiі вивчення користуватися доводилось здебільшого першоджерелами» (Гривінський, 2014). У світлі цього цілком виправданою є думка, що як у XIX столітті, так і в контексті сучасних подій творчість Тараса Шевченка лишається чи не найкращим орієнтиром для розуміння феномену гайдамаччини як у їі регіональному вимірі, так і в масштабах історії України у цілому.

\section{СПИСОК ВИКОРИСТАНИХ ДЖЕРЕЛ І ЛІТЕРАТУРИ}

Барановський, 2011 - Барановський О. А. Розгортання запорізького гайдамацтва на новосербському напрямку (1752 - 1764): джерелознавчий аналіз // Спеціальні історичні дисципліни: питання теорії та методики. Збірка наукових праць. К., 2011. С. 17-20.

Гончарук, Тихомир, 2008 - Гончарук П. С., Тихомир В. П. Т. Г. Шевченко про роль та місце в українській історії гайдамацьких рухів (до 240-річчя 
Коліївщини) // Вісник Державної академії керівних кадрів культури і мистецтв. 2008. № 3. C. 77-82.

Гривінський, 2014 - Гривінський Р. Шевченко як ключ до української ідентичності та історії // День. 2014 [Електронний ресурс]. Режим доступу до статті: http://incognita.day.kiev.ua/shevchenko-yak-klyuch-do-ukrayinskoyiidentichnosti-ta-istoriyi.html.

Записки Михаила Чайковского, 1891 - Записки Михаила Чайковского (Садык-паши) // Киевская старина. № 1. 1891. [Электронный ресурс]. Режим доступа: http:// www.vostlit.info/ Texts/Dokumenty/Turk/XIX/18201840/Sadyk_pasha/text1.htm.

Мицик, 2002 - Мицик Ю. А. Умань козацька та гайдамацька. К., 2002. $187 \mathrm{c}$.

Мільчев, 2005 - Мільчев В. І. Гайдамацтво на Нижньому Побужжі у 1750-х - на початку 1760-х років // Запорозька старовина. 2005. № 3. С. 48- 56.

Мірчук, 1973 - Мірчук П. Коліївщина [Електронний ресурс]. Режим доступу: http://exlibris.org.ua/hajdamaky/r03.html.

Мордовцев, 2003 - Мордовцев Д. Л. Гайдамаччина: Історична монографія. Дніпропетровськ, 2003. 359 с.

Омельчук, 2002 - Омельчук В. В. Народне повстання 1734-1738 рр. на Правобережній Україні та його місце у суспільно-політичному житті i міжнародних відносинах: дис... канд. іст. наук: 07.00.01. К., 2002. 206 с.

Посунько, 2010 - Посунько О. М. Запорозька Січ і Гайдамаччина у 50-ті на початку 60-x pp. XVIII ст. // Наддніпрянська Україна: історичні процеси, події, постаті. 2010. Вип. 8. С. 248- 259

Чухліб, 2008 - Чухліб Т. В. «Гайдамаччина» в Речі Посполитій XVIII ст. (причини повстанського руху в світлі джерел з українського табору) // Україна в Центрально-Східній Свропі (з найдавніших часів до кінця XVIII ст.). 2008. № 8. C. $116-125$

Шевченківська енциклопедія, 2012 - Шевченківська енциклопедія: В 6 т. Т. 2: Г-3. / Ред. колегія: М. Г. Жулинський (голова), М. П. Бондар, О. В. Боронь 
(відп. секретар) та ін. К., 2012. 760 с.

Шевченко, 2003а - Шевченко Т. Г. Повне зібрання творів: в 6 т. К., 2003. T. 5: Щоденник. Автобіографія. Статті. Археологічні нотатки. «Букварь южнорусский». Записи народної творчості. 2003. 496 с.

Шевченко, 2003b - Шевченко Т. Г. Повне зібрання творів: в 6 т. К., 2003. Т. 1: Поезія 1837-1847. 2003. 787 с.

\section{REFERENCES}

Baranovskyj, 2011 - Baranovskyj O. A. Rozgortannya zaporizkogo gajdamacztva na novoserbskomu napryamku (1752-1764): dzhereloznavchyj analiz [Deployment of Zaporizhian Haidamachyna on Novosebirsk direction (1752-1764): source study analysis] // Specialni istorychni dyscypliny: pytannya teoriyi ta metodyky. Zbirka naukovyx pracz. K., 2011. S. 17-20. [in Ukrainian].

Goncharuk, Tyxomyr, 2008 - Goncharuk P. S., Tyxomyr V. P. T. G. Shevchenko pro rol ta misce v ukrayinskij istoriyi gajdamaczkyx ruxiv (do 240richchya Koliyivshhyny) [Taras Shevchenko about the role and place in Ukrainian history of Haidamatskyi movements (dedicated to 240 years of Koliivschtchina)] // Visnyk Derzhavnoyi akademiyi kerivnyx kadriv kultury i mystecztv. 2008. № 3. S. 77-82. [in Ukrainian].

Gryvinskyj, 2014 - Gryvinskyj R. Shevchenko yak klyuch do ukrayinskoyi identychnosti ta istoriyi [Shevchenko as a key to Ukrainian identity and history] // Den. 2014 [Elektronnyj resurs]. Rezhym dostupu do statti: http://incognita.day.kiev.ua/shevchenko-yak-klyuch-do-ukrayinskoyi-identichnostita-istoriyi.html. [in Ukrainian].

Zapysky Myxayla Chajkovskogo, 1891 - Zapysky Myxayla Chajkovskogo (Sadyk-pashy) [Notes by Mikhail Tchaikovsky (Sadyk-Pasha)] // Kyevskaya staryna. № 1. 1891. [Elektronnyj resurs]. Rezhym dostupu: http:// www.vostlit.info/ Texts/Dokumenty/Turk/XIX/1820-1840/Sadyk_pasha/text1.htm. [in Ukrainian].

Mycyk, 2002 - Mycyk Yu. A. Uman kozaczka ta gajdamaczka [Cossack and Haidamatskyi Uman]. K., 2002. 187 s. [in Ukrainian]. 
Milchev, 2005 - Milchev V. I. Gajdamacztvo na Nyzhnomu Pobuzhzhi u 1750$\mathrm{x}$ - na pochatku 1760-x rokiv [Haidamachyna in Lower Pobuzhya in 1750-1760 years] // Zaporozka starovyna. 2005. № 3. S. 48-56. [in Ukrainian].

Mirchuk, 1973 - Mirchuk P. Koliyivshhyna [Koliyivshchyna] [Elektronnyj resurs]. - Rezhym dostupu: http://exlibris.org.ua/hajdamaky/r03.html.[in USA].

Mordovcev, 2003 - Mordovcev D. L. Gajdamachchyna: Istorychna monografiya [Haidamachyna: Historic monography]. Dnipropetrovsk, 2003. 359 s. [in Ukrainian].

Omelchuk, 2002 - Omelchuk V. V. Narodne povstannya 1734-1738 rr. na Pravoberezhnij Ukrayini ta jogo misce u suspilno-politychnomu zhytti i mizhnarodnyx vidnosynax [National rebellion 1734-1738 on right shore Ukraine and its place in social political life and international relationships]: dys... kand. ist. nauk: 07.00.01. K., 2002. 206 s. [in Ukrainian].

Posunko, 2010 - Posunko O. M. Zaporozka Sich i Gajdamachchyna u 50-ti - na pochatku 60-x rr. XVIII st. [Zaporizhian Sich and Haidamachyna in the fifties - at the beginning of sixties of the XVIII century] // Naddnipryanska Ukrayina: istorychni procesy, podiyi, postati. 2010. Vyp. 8. S. 248-259. [in Ukrainian].

Chuxlib, 2008 - Chuxlib T. V. «Gajdamachchyna» v Rechi Pospolytij XVIII st. (prychyny povstanskogo ruxu $\quad \mathrm{v}$ svitli dzherel $\mathrm{z}$ ukrayinskogo taboru) [«Haidamachyna» in Rich Pospolita of the XVIII century (reasons of rebellion movement on the background of sources of Ukrainian business] // Ukrayina $\mathrm{v}$ Centralno-Sxidnij Yevropi (z najdavnishyx chasiv do kincya XVIII st.). 2008. № 8. S. 116-125. [in Ukrainian].

Shevchenkivska encyklopediya, 2012 - Shevchenkivska encyklopediya [Shevchenko encyclopedia]: V 6 t. T. 2: G-Z. / Red. kolegiya: M. G. Zhulynskyj (golova), M. P. Bondar, O. V. Boron (vidp. sekretar) ta in. K., 2012. 760 s. [in Ukrainian].

Shevchenko, 2003a - Shevchenko T. G. Povne zibrannya tvoriv [Complete Collection of Works]: v 6 t. K., 2003. T. 5: Shhodennyk. Avtobiografiya. Statti. Arxeologichni notatky. «Bukvar yuzhnorusskyj». Zapysy narodnoyi tvorchosti. 2003. 496 s. [in Ukrainian]. 
Shevchenko, 2003b - Shevchenko T. G. Povne zibrannya tvoriv [Complete Collection of Works]. v 6 t. K., 2003. T. 1: Poeziya 1837-1847. 2003. 787 s. [in Ukrainian]. 